\title{
Water deficits during reproductive growth of soybeans. I. Their effects on dry matter accumulation, seed yield and its components
}

\author{
JM Andriani, FH Andrade *, EE Suero, JL Dardanelli \\ EEA Balcarce, Instituto Nacional de Tecnologia Agropecuaria (INTA), Facultad de Ciencias Agrarias, \\ Univ Nac de Mar Del Plata, CC 276, (7620) Balcarce, BS AS, Argentina
}

(Received 4 July 1990; accepted 30 June 1991)

\begin{abstract}
Summary - The objective of this study was to determine the effect of water deficits during the reproductive period of an indeterminate soybean (Glycine max (L) Merr) crop on growth, seed yield and its components, and to establish whether the $R_{1}-R_{4}$ or the $R_{4}-R_{6.3}$ period was the most sensitive to drought. Group maturity III cultivar Asgrow 3127 was planted in the 1986-1987 and 1987-1988 growing seasons on a loamy soil (typic argiudol). The trial consisted of 3 deficiency treatments starting with $50 \%$ of soil-available water at the soil depth explored by the roots at the time of initiation, and with a control (II) constantly maintained at $>50 \%$ of soil available water. The treatment drought periods were: 0 l) from $R_{1}$ to $R_{4} ; 10$ ) from $R_{4}$ to $R_{6.3}$; and 00 ) from $R_{1}$ to $R_{4}$ and from $R_{4}$ to $R_{6.3}$. Plots were individually irrigated and during the drought periods protected from rainfall with plastic covers. The control treatment (II) had greater dry matter production than $\mathrm{Ol}$ and $\mathrm{IO}$, and these 2 treatments produced more dry matter than 00 . Drought from $\mathrm{R}_{1}$ to $\mathrm{R}_{4}$ decreased leaf area production and drought from $R_{4}$ to $R_{6.3}$ accelerated leaf senescence. Leaf area index was related to percent solar radiation interception showing a critical LAI of $\approx 5.5$. Consequently, water deficits affected solar radiation interception. The reduction in PAR intercepted by the crop due to water deficits was no greater than $12 \%$. The utilization efficiency of the intercepted PAR that ranged from 1.5-1.9 g per MJ was clearly affected by the drought. Drought during the first period affected the vegetative growth with little effect on seed yield. This effect was reflected on harvest index and on dry matter remobilization efficiency. On the other hand, the reduction in crop growth rate induced by drought during the $R_{4}-R_{6.3}$ period was associated with important decreases in the number of reproductive structures per unit area as well as in total vegetative dry matter. The number of pods/ha was the yield component most affected by the treatments. For 01 , the number of seeds/pod and the weight of the seeds compensated the reduction in number of pods, relative to the control.
\end{abstract}

water deficit / Glycine max (L) Merr / dry matter production / seed yield / yield component / harvest index / leaf water potential / leaf area index / interception of radiation

Résumé - Déficit hydrique durant la phase reproductive du soja. I. Ses effets sur l'accumulation de la matière sèche, le rendement en grain et ses composants. L'effet d'un déficit hydrique durant la phase reproductive du soja a été étudié pendant 2 ans dans une expérience en conditions contrôlées en plein champ. Les traitements ont consisté en : (I) un témoin irrigué, et 3 périodes d'imposition de sécheresse, à savoir : Ol) sécheresse de $R_{1}$ à $R_{4} ; 10$ ) sécheresse de $R_{4}$ à $R_{6.3}$; et 00 ) sécheresse de $R_{1}$ à $R_{4}$ et de $R_{4}$ à $R_{6.3}$. Le témoin irrigué produisit une moyenne de $12 t$ de matière sèche/ha et $5 t$ de grains/ha. Une sécheresse imposée de $R_{1}$ à $R_{4}$ provoque une réduction de la surface foliaire et de la croissance végétative, avec seulement un léger effet sur le rendement en grain. Au contraire, une sécheresse imposée entre $R_{4}$ et $R_{6.3}$ diminue la production de matière sèche végétative et de graines. Le nombre de gousses $/ \mathrm{m}^{2}$ est la composante du rendement qui est la plus affectée par les traitements. En général, une augmentation du poids des graines compense dans le rendement la réduction du nombre de gousses.

déficit hydrique / Glycine max (L) Merr / production de matière sèche / rendement en graines / composantes du rendement / indice de récolte / potentiel hydrique de la feuille / indice de surface foliaire / radiation interceptée

\footnotetext{
* Correspondence and reprints
} 


\section{INTRODUCTION}

Water deficits affect growth and grain yield of crops (Hsiao, 1973; Shibles et al, 1975; Paleg and Aspinall, 1981; Rosenberg et al, 1983). However, the type and magnitude of the response depend on the intensity, duration and timing of the water deficiency.

Soybean seed yield is more affected by water stress during the flowering-pod setting period (Runge and Odell, 1960; Thompson, 1970; Ashley and Ethridge, 1978; Korte et al, 1983a; Kadhem et al, 1985a) and the seed filling period (Doss et al, 1974; Constable and Hearn, 1978; Brown et al, 1985; Griffin et al, 1985) than during the vegetative period.

The greatest modification in yield occurs through the number of pods/ha (Momen et al, 1979; Korte et al, 1983b; Pandey et al, 1984b; Kadhem et al, 1985b). The number of seeds/pod is quite stable and the 1000 seed weight is only reduced by water stress at the end of the reproductive cycle (Kadhem et al, 1985b).

In spite of the abundance of data related to the effect of water stress on soybean yields found in the literature, the differences in experimental conditions, cultivars (growth habits, maturity group, etc) and drought characteristics do not allow a clear definition to be made either of the relative sensitivity of different phenological stages or of how yield is affected.

In the area where this study was carried out (Balcarce, Bs As, Argentina) the average annual soybean yields for different cultivars have a wide variation (2 000 to $4000 \mathrm{~kg}$ of seed/ha) related to differences in the amount of rainfall during the seed filling period (Darwich, personal communication). However, no information is available on the real water deficits since no climatic demand or soil available water have been considered in previous works.

A field experiment was designed to control duration and intensity of water deficits in deep soils and under rather moderate evaporative demands by using semi-demountable covers and a high uniformity irrigation system. The objectives of the study were: a) to quantify the crop response to water stress during the reproductive period in terms of growth, seed yield and its components; and $b$ ) to identify the soybean reproductive subperiod $\left(R_{1}-R_{4}\right.$ or $\left.R_{4}-R_{6.3}\right)$ most sensitive to water stress.

\section{MATERIALS AND METHODS}

A field experiment was conducted at the National Institute for Agricultural Research (INTA) Experimental Station at Balcarce, Bs As, Argentina $\left(37^{\circ} 45^{\prime} \mathrm{S}, 58^{\circ}\right.$ $15^{\prime} \mathrm{W}$ ) during the 1986/1987 and 1987/1988 growing seasons. The soil was a typic argiudol (fine, illitic clay, thermic) with an organic matter content of $5.5 \%$, which has been fully described by Dardanelli et al (1991). Total soil available water was $300 \mathrm{~mm}$ (in $2 \mathrm{~m}$ of depth).

An indeterminate soybean maturity group III cultivar Asgrow 3127 was used. The plant population was thinned to 330000 and 270000 plants/ha the first and second year respectively. Soil fertility was adequate and weeds were correctly controlled.

The experiment was set in a completely randomized block design, with 4 treatments and 5 replications in 1986 and 3 replications in 1987. Each plot consisted of 10 rows, $0.7 \mathrm{~m}$ apart and $5.5 \mathrm{~m}$ long, surrounded by a ditch to collect excess water from the rain shelters or from irrigation or rainfall.

For the dry treatments, rainfall was excluded several days before the initiation of each deficiency, so that the period began with a percentage of soil available water (PAW) of around 50. This was done by covering each plot so the plants grew only on water stored in the soil profile. Individually hand-operated shelters permitted plots to be covered with a propylene sheet $(0.15 \mathrm{~mm}$ thick) that was unrolled during rainfall.

Three dry treatments were imposed during the following periods (adapted from Fehr and Caviness, 1977) : R1-R4 (0l); R4-R6.3 (I0); and both R1-R4 and R4-R6.3 (00). For the remaining time PAW was kept $>50$ as in the control treatment (II). When necessary, water was applied to reach the soil storage upper limit (UL) using a sprinkler irrigation system specially designed by Shouse et al (1982) for individual plots.

Soil water measurements and calculation have been explained by Dardanelli et al (1991).

Table I presents the meteorological data and irrigation applied to treatment II for the 2 growing cycles.

At physiological maturity, $5.6 \mathrm{~m}^{2}$ were harvested in the 2 central rows for seed and yield components. Plant samples were obtained at the $V_{3}, R_{1}, R_{2.5}, R_{4}$, $R_{5.5}, R_{6.3}$ and $R_{8}$ stages. The sampling area was 0.7 $\mathrm{m}^{2}$ and $1.4 \mathrm{~m}^{2}$ for the first and second year respectively. Plants were fractionated into leaf blades, stems and petioles and carpels and seeds. Fallen leaves were collected with baskets placed between rows. All fractions were oven-dried at $60^{\circ} \mathrm{C}$ to constant weight. Seed weight was corrected to $13 \%$ moisture. Leaf area index was measured with an area meter ACC400, Hayashi Denkob Co, Ltd, Japan.

Every 5 to 7 days during the time of drought application, leaf water potential was measured with a Schollander type pressure chamber on the second youngest expanded leaf at predawn (PWP) corresponding to the moment of maximum plant water content. 
Table I. Mean daily photosynthetically active radiation, maximum and minimum mean temperatures, precipitation and irrigation for 10-day periods.

\begin{tabular}{|c|c|c|c|c|c|c|c|c|c|c|c|c|c|c|c|c|}
\hline \multirow{3}{*}{$\begin{array}{l}\text { PAR } \\
\text { MJ m-2.d-1 }\end{array}$} & \multirow{2}{*}{$\begin{array}{c}\text { Year } \\
86 / 87\end{array}$} & \multicolumn{3}{|c|}{ November } & \multicolumn{3}{|c|}{ December } & \multicolumn{3}{|c|}{ January } & \multicolumn{3}{|c|}{ February } & \multicolumn{3}{|c|}{ March } \\
\hline & & 9.2 & 10.6 & 10.4 & 12.4 & 12.9 & 10.9 & 12.4 & 13.7 & 12.5 & 10.2 & 11.7 & 7.8 & 6.5 & 7.6 & 5.7 \\
\hline & $87 / 88$ & 9.2 & 10.4 & 10.6 & 13.0 & 11.2 & 9.2 & 12.5 & 12.2 & 8.8 & 9.5 & 9.0 & 8.7 & 7.5 & 6.4 & 6.7 \\
\hline$T_{\max }$ & $86 / 87$ & 18.8 & 24.0 & 22.3 & 23.8 & 24.2 & 25.5 & 26.2 & 27.6 & 29.8 & 28.0 & 29.9 & 29.6 & 24.8 & 22.1 & 21.0 \\
\hline${ }^{\circ} \mathrm{C}$ & $87 / 88$ & 19.2 & 23.0 & 25.1 & 24.0 & 22.4 & 23.4 & 28.8 & 28.8 & 23.8 & 23.8 & 23.8 & 27.0 & 25.2 & 23.5 & 24.4 \\
\hline$T_{\min }$ & $86 / 87$ & 7.0 & 9.0 & 10.4 & 9.8 & 10.2 & 12.8 & 10.4 & 11.8 & 12.7 & 13.9 & 14.9 & 16.2 & 14.4 & 9.8 & 12.2 \\
\hline$\left({ }^{\circ} \mathrm{C}\right)$ & $87 / 88$ & 7.8 & 9.8 & 11.0 & 9.0 & 9.0 & 10.7 & 13.0 & 11.8 & 11.7 & 8.2 & 10.5 & 15.0 & 11.2 & 14.0 & 11.5 \\
\hline $\begin{array}{l}\text { Precipitation } \\
(\mathrm{mm})\end{array}$ & $\begin{array}{l}86 / 87 \\
87 / 88\end{array}$ & $\begin{array}{l}30 \\
50\end{array}$ & $\begin{array}{r}110 \\
8\end{array}$ & $\begin{array}{r}59 \\
8\end{array}$ & $\begin{array}{l}28 \\
30\end{array}$ & $\begin{array}{r}7 \\
75\end{array}$ & $\begin{array}{r}4 \\
33\end{array}$ & $\begin{array}{l}12 \\
30\end{array}$ & $\begin{array}{r}20 \\
6\end{array}$ & $\begin{array}{l}30 \\
86\end{array}$ & $\begin{array}{l}35 \\
40\end{array}$ & $\begin{array}{c}8 \\
16\end{array}$ & $\begin{array}{r}25 \\
0\end{array}$ & $\begin{array}{r}66 \\
2\end{array}$ & $\begin{array}{c}10 \\
34\end{array}$ & $\begin{array}{r}8 \\
48\end{array}$ \\
\hline Irrigation & $86 / 87$ & 0 & 0 & 0 & 0 & 0 & 38 & 28 & 42 & 65 & 52 & 80 & 0 & 0 & 0 & 0 \\
\hline Treat II (mm) & $87 / 88$ & 0 & 0 & 0 & 0 & 0 & 0 & 0 & 80 & 0 & 44 & 45 & 60 & 36 & 20 & 0 \\
\hline
\end{tabular}

Periodic measurements of photosynthetically active radiation (PAR) were taken at solar noon, with a radiometer $\mathrm{LI} 188 \mathrm{~B}$ connected to a line quantum sensor $\mathrm{LI}$ 191 SB (Licor Inc, USA) (5 replications per plot).

The percentage of PAR intercepted by the crop was calculated as :

$$
\% \text { PAR int }=100 \times(1-1 / / 0)
$$

$I$ and 10 being the PAR measured at ground level and at the top of the canopy, respectively.

Total PAR intercepted by the crop during a particular period $\left(\mathrm{MJ} / \mathrm{m}^{2}\right)$ was obtained as:

$$
\text { PAR int }=(\% \text { PAR int } \times \text { PAR inc }) / 100
$$

where PAR inc is the incoming PAR for that period.

The utilization efficiency (ec) of intercepted PAR was obtained as :

$$
e c=\Delta \mathrm{DM} / \mathrm{PAR} \text { int }
$$

$\triangle D M$ being the dry matter increment during the period in $\mathrm{g} / \mathrm{m}^{2}$ and PAR int the total PAR intercepted during the same period.

Harvest index $(H I)$ was calculated as seed yield/ total above ground biomass at physiological maturity.

Dry matter remobilization efficiency (DMRe) at the end of the growing cycle was estimated as :

$$
\mathrm{DMRe}=(V B-T B) / V B
$$

where $V B$ is the vegetative biomass plus pod walls at $R_{6.3}$ and $T B$ is the total biomass minus seed yield at physiological maturity; $V B$ and $T B$ include fallen leaves.

Analysis of variance was applied to the data, and Duncan's multiple range test $(P=0.05)$ was used for treatment means comparison.

\section{RESULTS AND DISCUSSION}

\section{Water availability and plant water status}

Figure 1 shows the volumetric soil water content for the II, OI and 10 treatments. The soil water content clearly reflected the different treatments. An important decrease in available water was observed in the upper layers of the soil profile when drought was applied at the beginning of the reproductive period $\left(R_{1}-R_{4}\right)$, treatments 0 I and 00$)$. In the second period of drought $\left(R_{4^{-}}\right.$ $R_{6.3}$, treatments 10 and 00 ), the stressed treatments showed a decrease in soil water content mainly in deep layers. In the control treatment, the soil water content was kept near the upper limit of soil water availability throughout the growing cycle.

At the beginning of the drought periods, the PAW in the soil reached by the roots was $\approx 50$ in 1986-1987 and 50 in 1987-1988; moreover, at the end of these periods the values dropped to 42,32 and 30 in the first year and 42,37 and 35 in the second year for 01,10 and 00 respectively. Notice that up to $R_{4}$, the drought treatments explored deeper layers of soil than the control.

Figure 2 shows the influence of the water deficiencies of predawn leaf water potential (PWP). The higher values in water potential in 19871988 were a consequence of the higher PAW.

The larger differences in leaf water potential at $R_{6.3}$ compared to $R_{4}$ between stressed and non stressed treatments were probably due to a 
(a)
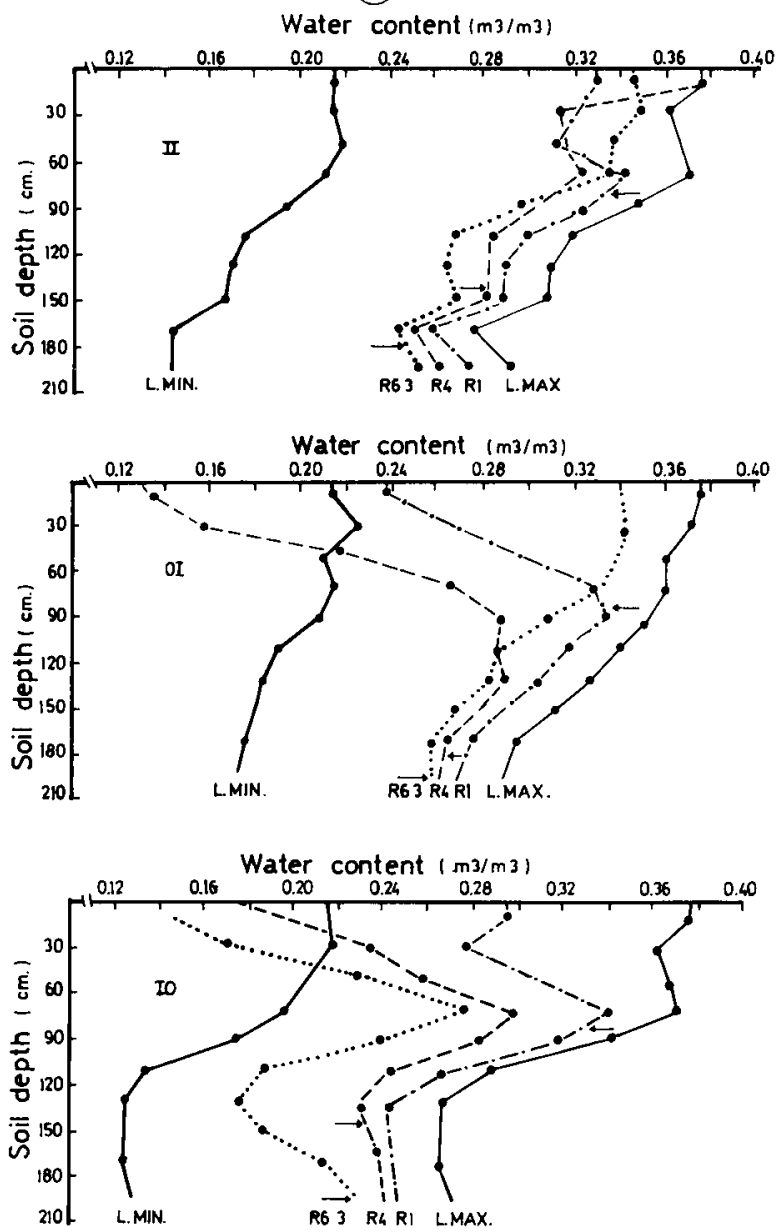

(b)
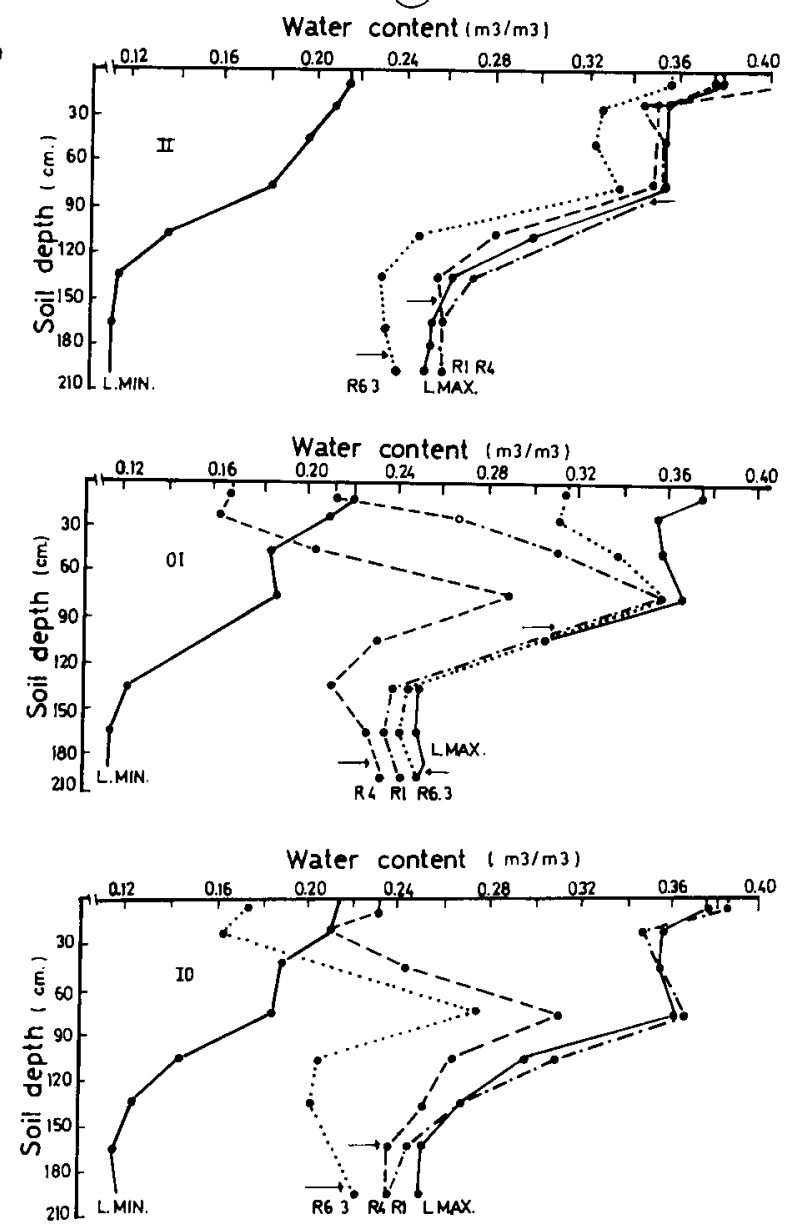

Fig 1. Volumetric soil water content at different phenological periods for all the treatments, for the 1986-1987 (1a) and 1987-1988 (1b) growing seasons. $L_{\min }$ and $L_{\max }$ are the lower and upper limits of soil available water, respectively. Arrows indicate root depth.

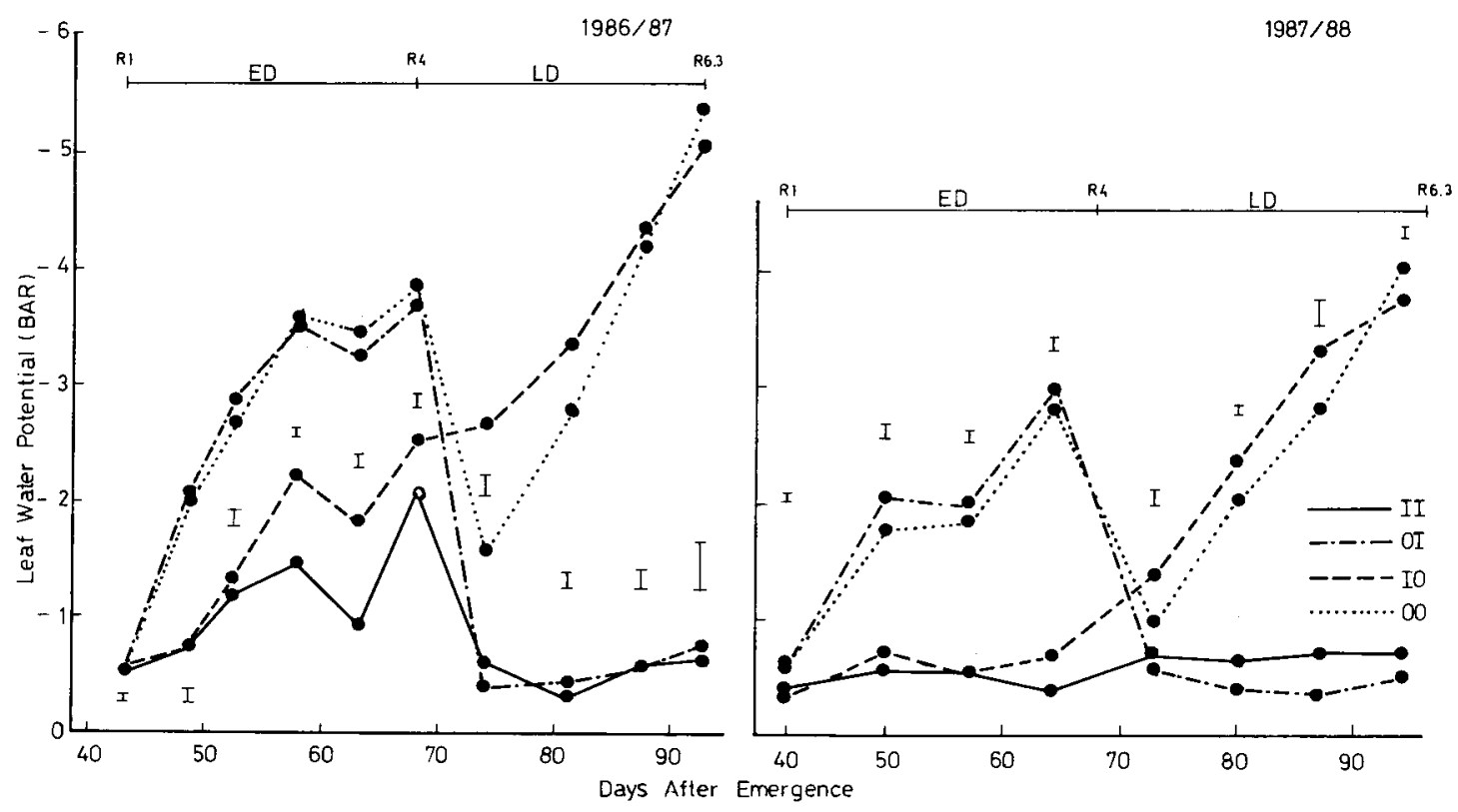

Fig 2. Soybean predawn leaf water potential (PWP) during the early (ED) and late (LD) deficiency periods for all the treatments in both years. Bars indicate the SEM. 
greater transpiratory surface at $R_{6.3}$ and to the fact that at the middle of the second drought period the roots reached their maximum exploration volume (Dardanelli et al, 1991). During the first 80 days after emergence the roots explored deeper zones. This produced a rapid decrease in the water potential gradient between the leaf and the soil during the night.

\section{Dry matter production}

Total above ground dry matter (DM) accumulation was modified by the drought treatments (fig 3). Significant differences between wet and dry treatments were found at the end of both drought periods in both years.

Because of the restoration of good soil water conditions in $\mathrm{Ol}$ and the increasing water deficiency in 10, no differences in DM were found between these 2 treatments at $R_{6.3}$. At this particular period, both treatments presented lower DM than the control (II) and higher than 00. At harvest, average reduction in DM with respect to the control was $26 \%$ for 01 and 10 , and $35 \%$ for 00 . The 2-year combined analysis showed a greater DM production for the second year, in agreement with the higher values of PWP. From $R_{1}$ on, DM accumulation was in agreement with the soil and plant indicators of water deficiencies (PAW, PWP).
Vegetative biomass (stem, leaves and petioles) and plant height showed the same trend as total biomass (table II). At the end of the season, the vegetative DM represented $46,44,37$ and $38 \%$ of the total DM for treatments $11,10,01$ and 00 , respectively. The lower values for the treatments 01 and 00 show the effect of the first period of drought on vegetative growth.

Crop growth rate (CGR) was affected by water deficiencies from $R_{1}$ to $R_{6.3}$. From $R_{6.3}$ to physiological maturity, no differences in CGR were found among treatments (see slopes in fig 3).

Crop productivity depends on the development of leaf area to intercept solar energy and on photosynthesis to convert this energy into dry matter (Turner and Begg, 1981). Figure 4 shows LAl evolution. At the end of the first drought period $\left(R_{4}\right)$ the treatments under water deficiency $(00$, ol) showed lower LAl than the wet treatments (II, I0). Cell enlargement (leaf expansion) was reported as the first process affected by water deficits (Hsiao, 1973; Kramer, 1983). During the second drought period $\left(\mathrm{R}_{4}-\mathrm{R}_{6.3}\right)$ treatment 10 lost a significant amount of leaves, because water deficits produced an acceleration of senescence (Ludlow, 1975; Legg et al, 1979). This phenomenon was indicated as an adaptation to water stress (Hall et al, 1979; Turner and Begg, 1981). On the other hand, treatment ol resulted in continued production of new leaves.

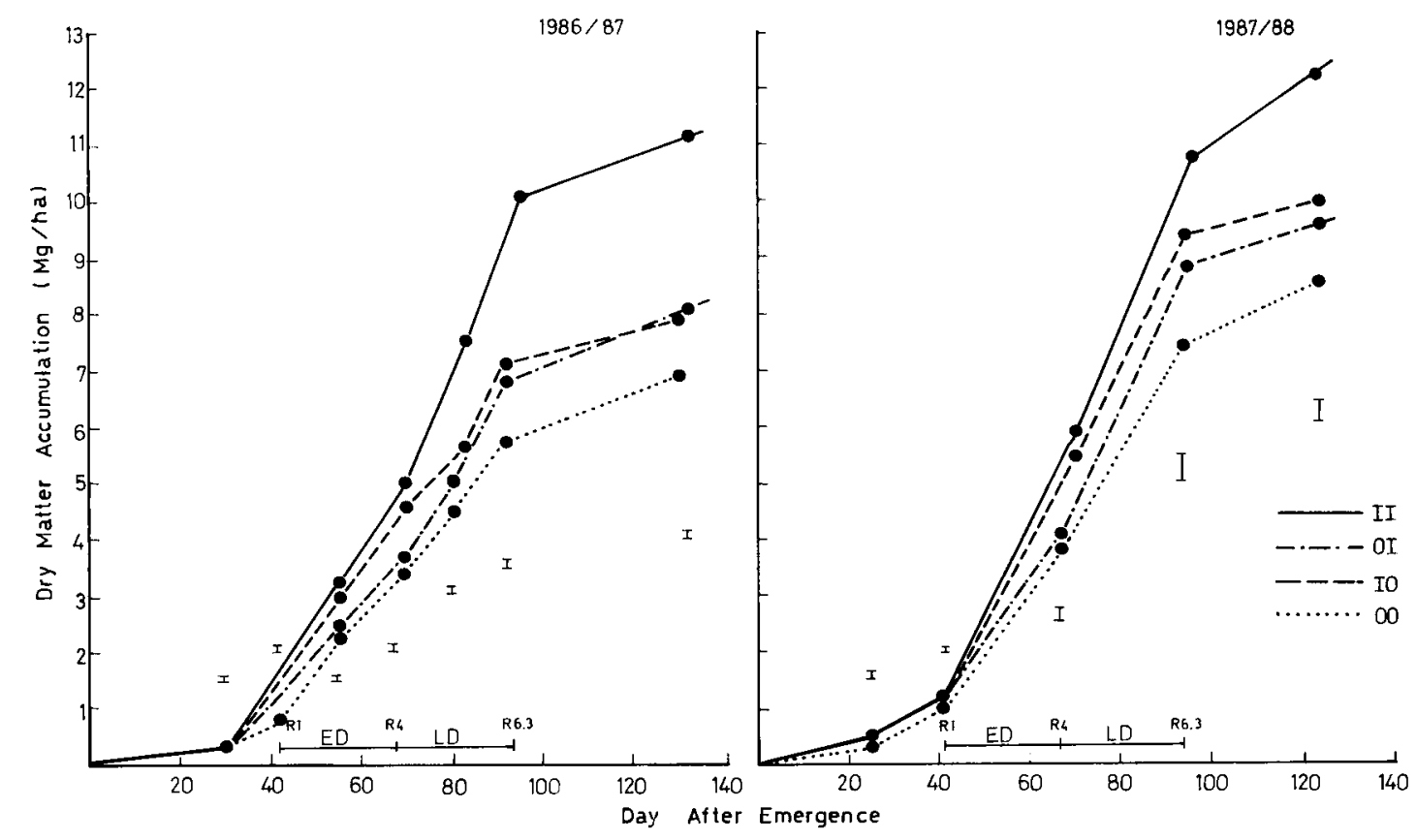

Fig 3. Soybean above ground dry matter accumulation as a function of time after emergence for all the treatments in both years. Bars indicate the SEM. 
Table II. Soybean total vegetative biomass (leaves + fallen leaves + petioles + stems), reproductive biomass (carpels + seeds) and plant height, for the different treatments at different phenological stages. Averages for $1986-1987$ and 1987-1988.

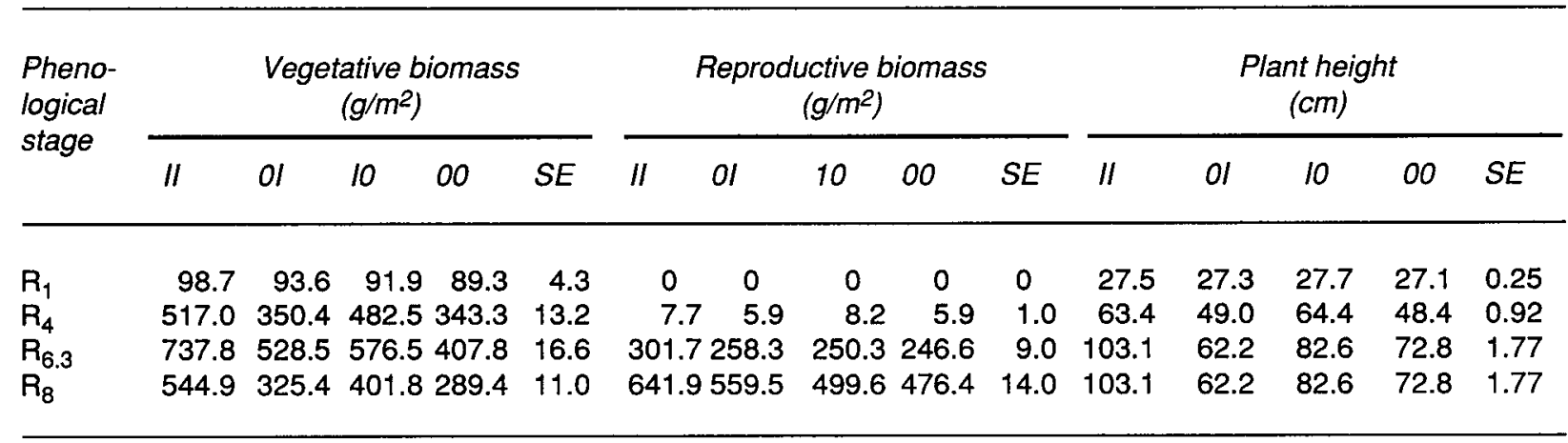

$S E=$ standard error of the mean.

LAI was related to the percentage of PAR interception (\% PAR int) showing a critical LAI value of $\approx 5.5$. This value was greater than that reported by Shibles and Weber (1966) for maturity group II soybeans. As a consequence of the reduction in LAl, \% PAR int in the dry treatments was affected (fig 5). Water deficits in the first period $(00,01)$ did not allow the crop to achieve the 95\% PAR interception (fig 5). The loss of leaves in 10 and the production of new leaves in 01 after $\mathrm{R}_{4}$ resulted in similar \% PAR int for these 2 treatments at $R_{6.3}$.

The average daily values of total PAR intercepted by the crop during the 2 drought periods are shown in table III. Since drought was applied when a relative high \% PAR int was already es- tablished, the 2 years average reduction in total PAR int was small (no greater than $12 \%$ ).

The utilization efficiency of the intercepted PAR $(e c)$ is also presented in table III. Water deficits during any or both periods clearly reduce $e c$ compared to control. Shibles and Weber (1966) reported a close relationship between CGR and intercepted radiation with $e c$ ranging from 1 to $1.4 \mathrm{~g} \mathrm{DM} / \mathrm{MJ}$ of intercepted PAR. In this work, efficiencies were within that range only for the dry treatments. With good water supply, average $e c$ ranged from $1.5-1.9 \mathrm{~g} / \mathrm{MJ}$.

The lower efficiency in the dry treatments was related to an increase in stomatal resistance (LR) to carbon dioxide fixation (see Dardanelli et al, 1991). However, Farquar and Sharkey (1982),

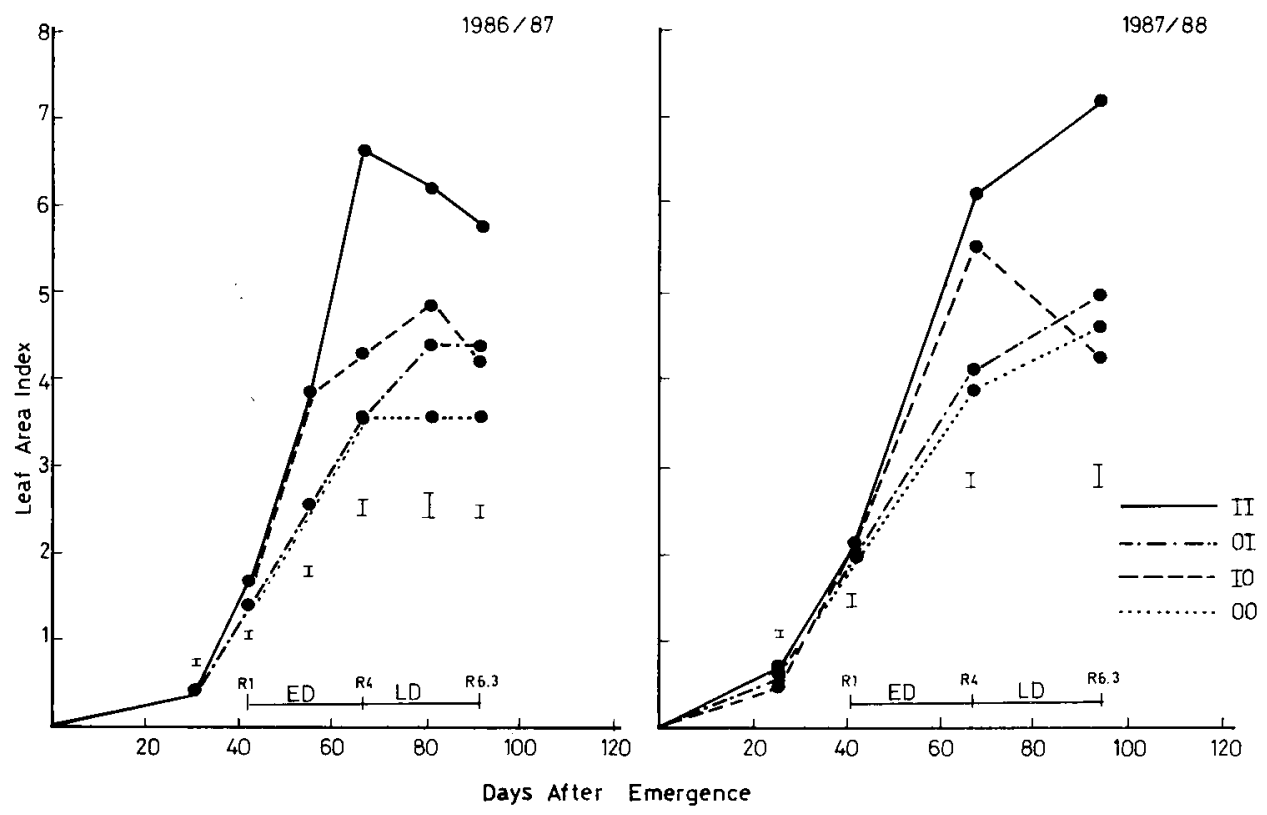

Fig 4. Soybean leaf area index (LAl) evolution for the different treatment in hoth years. Bars indicate the SEM. 

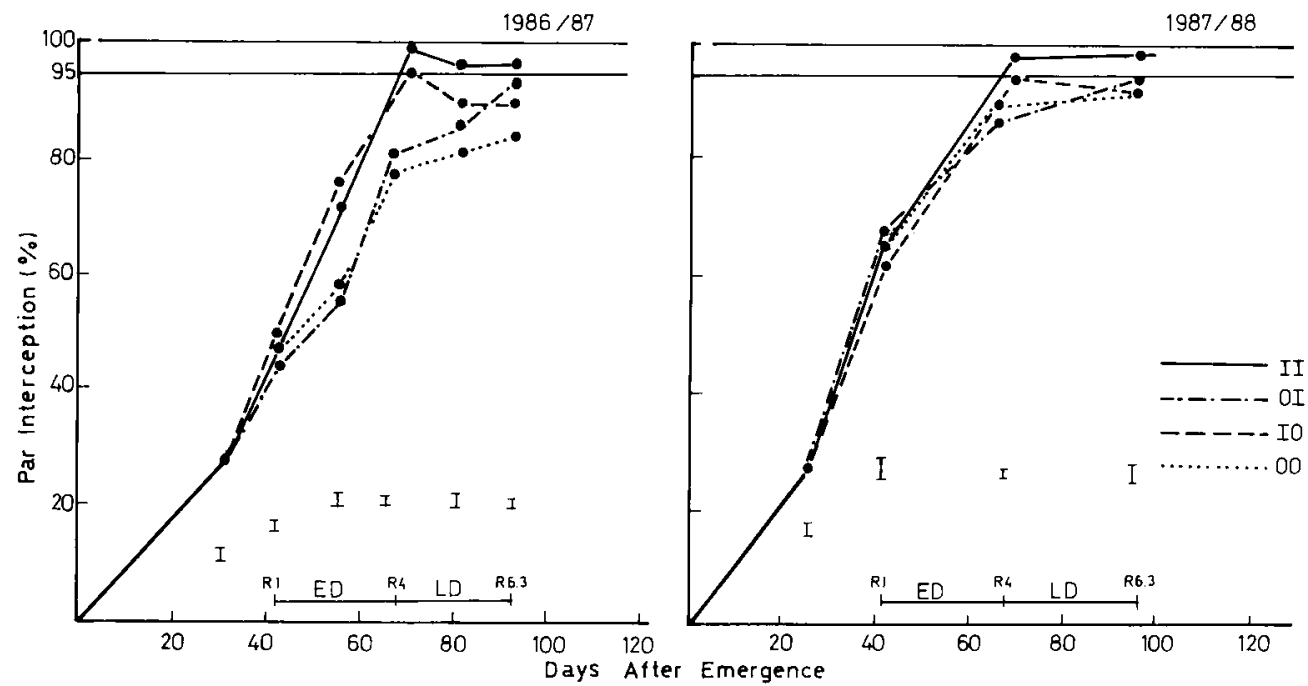

Fig 5. Percent of photosynthetically active radiation interception along the growing season for the different treatments. Bars represent the SEM.

mentioned than an increase in LR under drought is not necessarily the cause of a lower efficiency.

The 2-year combined analysis of variance for CGR and $e c$ showed a significant year $x$ treatment interaction for the second period of drought. The drought produced a larger decrease in CGR and $e c$ in the first year than that found in the second year. This interaction was due to a lower at- mospheric demand during this period in the second year. The average potential evapotranspiration (PET) for this period was $4.8 \mathrm{~mm} /$ day and 6 $\mathrm{mm} / \mathrm{day}$ for the second and first year, respectively (Dardanelli et al, 1991). During the first year, higher radiation favoured the well watered control (II) but this higher radiation, together with a higher demand, increased water stress in the dry treatments $(10,00)$ (table III).

Table III. Average daily photosynthetically active radiation intercepted (PAR int) and utilization efficiency of the intercepted radiation $(e c)$ by the crop canopies at different phenological periods.

\begin{tabular}{|c|c|c|c|c|c|c|c|}
\hline \multirow[t]{2}{*}{ Treatment } & \multirow[t]{2}{*}{ Year } & \multicolumn{2}{|c|}{ Period $V_{3}-R_{1}$} & \multicolumn{2}{|c|}{ Period $R_{1}-R_{4}$} & \multicolumn{2}{|c|}{ Period $R_{4}-R_{6.3}$} \\
\hline & & $\begin{array}{r}\text { PAR int } \\
\left(M J . m^{-2}\right)\end{array}$ & $\begin{array}{c}e c \\
(g . M J)\end{array}$ & $\begin{array}{c}\text { PAR int } \\
\left(M J \cdot m^{-2}\right)\end{array}$ & $\begin{array}{c}e c \\
\left(g . M J^{-1}\right)\end{array}$ & $\begin{array}{l}\text { PAR int } \\
\left(M J . m^{-2}\right)\end{array}$ & $\begin{array}{c}e c \\
\left(g \cdot M \digamma^{-1}\right)\end{array}$ \\
\hline II & $\begin{array}{l}86 / 87 \\
87 / 88 \\
\bar{X}\end{array}$ & $\begin{array}{l}4.44 \\
5.50 \\
4.97\end{array}$ & $\begin{array}{l}1.18 \\
0.87 \\
1.03\end{array}$ & $\begin{array}{l}9.36 \\
9.96 \\
9.66\end{array}$ & $\begin{array}{l}1.64 \\
1.58 \\
1.61\end{array}$ & $\begin{array}{r}11.50 \\
9.07 \\
10.29\end{array}$ & $\begin{array}{l}1.86 \\
1.97 \\
1.92\end{array}$ \\
\hline 이 & $\begin{array}{l}86 / 87 \\
87 / 88 \\
\bar{X}\end{array}$ & $\begin{array}{l}4.35 \\
5.78 \\
5.07\end{array}$ & $\begin{array}{l}1.02 \\
0.86 \\
0.94\end{array}$ & $\begin{array}{l}8.10 \\
9.54 \\
8.82\end{array}$ & $\begin{array}{l}1.28 \\
1.16 \\
1.22\end{array}$ & $\begin{array}{r}10.14 \\
8.56 \\
9.37\end{array}$ & $\begin{array}{l}1.42 \\
1.95 \\
1.69\end{array}$ \\
\hline 10 & $\begin{array}{l}86 / 87 \\
87 / 88 \\
\bar{X}\end{array}$ & $\begin{array}{l}4.55 \\
5.51 \\
5.03\end{array}$ & $\begin{array}{l}0.91 \\
0.87 \\
0.89\end{array}$ & $\begin{array}{l}9.44 \\
9.55 \\
9.50\end{array}$ & $\begin{array}{l}1.50 \\
1.55 \\
1.53\end{array}$ & $\begin{array}{r}10.71 \\
8.77 \\
9.74\end{array}$ & $\begin{array}{l}1.07 \\
1.77 \\
1.42\end{array}$ \\
\hline 00 & $\begin{array}{l}86 / 87 \\
\frac{87 / 88}{\bar{X}}\end{array}$ & $\begin{array}{l}4.52 \\
5.71 \\
5.12\end{array}$ & $\begin{array}{l}0.96 \\
0.81 \\
0.89\end{array}$ & $\begin{array}{l}8.37 \\
9.56 \\
8.97\end{array}$ & $\begin{array}{l}1.22 \\
1.16 \\
1.19\end{array}$ & $\begin{array}{l}9.50 \\
8.56 \\
9.03\end{array}$ & $\begin{array}{l}1.07 \\
1.43 \\
1.25\end{array}$ \\
\hline $\begin{array}{l}\text { SE } \\
\text { SE }\end{array}$ & $\begin{array}{l}86 / 87 \\
87 / 88\end{array}$ & $\begin{array}{l}0.18 \\
0.16\end{array}$ & $\begin{array}{l}0.06 \\
0.05\end{array}$ & $\begin{array}{l}0.15 \\
0.22\end{array}$ & $\begin{array}{l}0.07 \\
0.06\end{array}$ & $\begin{array}{l}0.11 \\
0.06\end{array}$ & $\begin{array}{l}0.08 \\
0.13\end{array}$ \\
\hline
\end{tabular}

$\mathrm{SE}=$ Standard error of the mean. 


\section{Seed yield}

The 2-year combined analysis for seed yield showed significant differences between years and among treatments with no treatment $x$ year interaction. The yield of the control treatment (II) did not statistically differ from the ol yield and both treatments produced higher yields than 10 and 00 (table IV).

The absence of differences between II and ol and between 10 and 00 indicates that water deficits during the first period of drought $\left(\mathrm{R}_{1}-\mathrm{R}_{4}\right)$ did not affect seed yield.

As drought progressed during the first period $\left(R_{1}-R_{4}\right)$ the roots explored deeper zones with higher PAW, and in the middle of the second drought period, the roots reached their maximum exploration volume (Dardanelli et al, 1991). This could explain the higher susceptibility of soybean grain yield to water deficits during the second drought period $\left(R_{4}-R_{6.3}\right)$. However, the drought significantly affected crop growth rate (CGR) and conversion efficiency $(e c)$ during both periods. Then, the lower sensitivity of grain yield to drought at the $R_{1}-R_{4}$ period can be attributed to the plasticity of the flowering and pod formation period, that allowed the generation of new flowers and pods with more and heavier seeds rela- tive to the control, upon irrigation at $R_{4}$. Moreover, growth and $e c$ were more affected by the late deficient treatments in the first year while seed yield was affected in a similar way by this treatment in both years. This suggests a direct effect of water stress during the $R_{4}-R_{6.3}$ period on soybean reproductive structures.

In agreement with these findings, Constable and Hearn (1978) and Snyder et al (1982), found that the $R_{5}-R_{7}$ period was the most sensitive for indeterminate soybeans. On the other hand, Kadhem et al (1985a) concluded that the $R_{3}-R_{4}$ period showed the best response to irrigation. In this work, drought at the $R_{4}-R_{6.3}$ period was more detrimental to seed yield of indeterminate soybean than drought at the $R_{1}-R_{4}$ period.

For all treatments, seed yield was higher in 1987-1988 than in 1986-1987 (table IV). This was related to a larger water content in the soil explored by the roots in the second growing season.

\section{Yield components}

The number of pods/ha, the number of seeds/ pod and the weight of the seeds were affected by water deficits (table IV). The 2-year combined

Table IV. Numbers of plants/ha, pods/ha, seeds/pod, 1000 seed weight, seed yield, harvest index and dry matter remobilization efficiency (DMRe), for the different treatments at harvest.

\begin{tabular}{|c|c|c|c|c|c|c|c|c|}
\hline Treatment & Year & $\begin{array}{c}\text { Thousands } \\
\text { plants/ha }\end{array}$ & $\begin{array}{c}\text { Millions } \\
\text { pods/ha }\end{array}$ & $\begin{array}{c}\text { No of } \\
\text { seeds/pod }\end{array}$ & $\begin{array}{c}\text { Weight } \\
1000 \text { seeds } \\
\text { (g) }\end{array}$ & $\begin{array}{c}\text { Seed yield } \\
(\text { t/ha-1) }\end{array}$ & $\begin{array}{l}\text { Harvest } \\
\text { (index } \times 100 \text { ) }\end{array}$ & $D M R e$ \\
\hline II & $\begin{array}{l}86 / 87 \\
\frac{87 / 88}{\bar{X}}\end{array}$ & $\begin{array}{l}330 \\
260 \\
295\end{array}$ & $\begin{array}{l}11.03 \\
12.74 \\
11.88 \mathrm{a}\end{array}$ & $\begin{array}{l}2.37 \\
2.28 \\
2.33 b\end{array}$ & $\begin{array}{l}175 \\
189 \\
182 \mathrm{c}\end{array}$ & $\begin{array}{l}4.56 \\
5.51 \\
5.03 \mathrm{a}\end{array}$ & $\begin{array}{l}36.2 \\
39.2 \\
37.7 \mathrm{c}\end{array}$ & $\begin{array}{l}20.6 \\
18.5 \\
19.6 b\end{array}$ \\
\hline 이 & $\begin{array}{l}86 / 87 \\
\frac{87 / 88}{X}\end{array}$ & $\begin{array}{l}324 \\
270 \\
297\end{array}$ & $\begin{array}{l}9.58 \\
10.14 \\
9.86 \mathrm{~b}\end{array}$ & $\begin{array}{l}2.43 \\
2.44 \\
2.44 \mathrm{a}\end{array}$ & $\begin{array}{l}190 \\
198 \\
194 b\end{array}$ & $\begin{array}{l}4.43 \\
4.89 \\
4.66 \mathrm{a}\end{array}$ & $\begin{array}{l}48.4 \\
44.6 \\
46.5 a\end{array}$ & $\begin{array}{l}26.7 \\
29.1 \\
27.9 a\end{array}$ \\
\hline 이 & $\begin{array}{l}86 / 87 \\
87 / 88 \\
\bar{X}\end{array}$ & $\begin{array}{l}334 \\
270 \\
302\end{array}$ & $\begin{array}{l}8.15 \\
8.97 \\
8.56 \mathrm{c}\end{array}$ & $\begin{array}{l}2.36 \\
2.25 \\
2.31 b\end{array}$ & $\begin{array}{l}197 \\
220 \\
209 a\end{array}$ & $\begin{array}{l}3.78 \\
4.42 \\
4.10 \mathrm{~b}\end{array}$ & $\begin{array}{l}42.4 \\
39.9 \\
41.2 \mathrm{~b}\end{array}$ & $\begin{array}{l}21.7 \\
22.6 \\
22.2 b\end{array}$ \\
\hline 00 & $\begin{array}{l}86 / 87 \\
87 / 88 \\
\bar{X}\end{array}$ & $\begin{array}{l}330 \\
277 \\
304\end{array}$ & $\begin{array}{l}7.70 \\
8.93 \\
8.31 \mathrm{c}\end{array}$ & $\begin{array}{l}2.39 \\
2.36 \\
2.38 \mathrm{ab}\end{array}$ & $\begin{array}{l}194 \\
211 \\
203 a\end{array}$ & $\begin{array}{l}3.57 \\
4.44 \\
4.00 \mathrm{~b}\end{array}$ & $\begin{array}{l}46.0 \\
450.2 \\
45.6 \mathrm{a}\end{array}$ & $\begin{array}{l}20.0 \\
20.8 \\
20.4 b\end{array}$ \\
\hline $\begin{array}{l}\text { SE } \\
\text { SE }\end{array}$ & $\begin{array}{l}86 / 87 \\
87 / 88\end{array}$ & $\begin{array}{l}10 \\
36\end{array}$ & $\begin{array}{l}0.24 \\
0.45\end{array}$ & $\begin{array}{l}0.04 \\
0.02\end{array}$ & $\begin{array}{l}2.5 \\
4.0\end{array}$ & $\begin{array}{l}0.14 \\
0.19\end{array}$ & $\begin{array}{l}0.9 \\
1.1\end{array}$ & $\begin{array}{l}0.9 \\
1.4\end{array}$ \\
\hline
\end{tabular}


analysis for yield components showed no significant year $x$ treatment interaction. The control had a significantly higher number of pods/ha than the rest of the treatments. Moreover, 01 has a larger number of pods/ha than 10 and 00 . Water deficits produced a lower number of pods/ha. This could be explained by a reduction in flower production and by an increase in flower abortion (Sionit and Kramer, 1977; Pandey et al, 1984a). The larger pod production of ol treatment with respect to 10 and 00 was the consequence of the generation of new flowers upon irrigation in $0 \mathrm{l}$ at $R_{4}$, and the abortion of pods in 10 and 00 starting at $R_{4}$. These 2 treatments had small to null production of new pods from $R_{4}$, in agreement with the findings of Momem et al (1979).

In Ol, the growth of pods under good soil available water and with low competition for assimilates among the pods produced an increase in the number of seeds/pod.

In $\mathrm{II}$ and $\mathrm{Ol}$, the larger number of seeds brought about more competition for carbohydrates producing lower seed size (treatments 10 and 00 had significantly larger seeds than II and ol). The increase in the number of reproductive sinks did not produce an increase in CGR from $R_{6.3}$ to physiological maturity. These data suggest a limited source capacity.

The treatments with the highest number of seeds/ha translocated more dry matter from the vegetative parts and pod walls to the seeds (data not shown). This is further proof of high competition for carbohydrates among the seeds in these treatments.

The number of pods/ha is the main soybean yield component (Herbest and Litchfield, 1982; Rogers et al, 1984). In consequence, when it is affected by water deficits, seed yield is diminished, except when the deficiency occurs early in the reproductive period. Upon irrigation, the capacity of this indete-minante variety to produce new pods and to form pods with more and heavier seeds allowed the ol treatment to reach a yield statistically similar to that of the control (II).

\section{Harvest index}

Vegetative growth and yield and consequently harvest index were affected by water deficiencies depending on the time at which the deficiencies were imposed, as was also found by Korte et al (1983b) and Meckel et al (1984).
Drought during the $R_{4}-R_{6.3}$ period produced an important decrease in the number of reproductive structures per unit area as well as in total vegetative dry matter (plus pod walls).

On the other hand, drought during the $R_{1}-R_{4}$ period decrease the vegetative dry matter production with no significant effect on seed yield. Similar results were presented by Egli et al (1983) and Snyder et al (1982) for indeterminate soybean cultivars. For this reason, treatment ol presented the highest DMRe and treatments ol and 00 had higher harvest index $(H I)$ than the rest of the treatments (II, 10). This does not agree with the data presented by Pandey et al (1984a), who established a positive linear relationship between $\mathrm{HI}$ and the amount of water supplied to the crop.

\section{REFERENCES}

Ashley DA, Ethridge WJ (1978) Irrigation effects on vegetative and reproductive development of three soybean cultivars. Agron J 70, 467-471

Brown EA, Cavines CE, Brown DA (1985) Response of selected soybean cultivars to soil moisture deficit. Agron J 77, 274-278

Constable FA, Hearn AB (1978) Agronomic and physiological responses of soybean and sorghum crops to water deficits: I. Growth, development and yield. Aust J Plant Physiol 5, 159-167

Dardanelli J, Suero E, Andrade FH, Andriani JM (1991) Water deficits during reproductive growth of soybeans : II. Water use and water deficiency indicators. Agronomie 11 (9), 747-756

Doss VD, Pearson RW, Rogers HT (1974) Effect of soil water stress at various growth stages on soybean. Agron J66, 297-299

Egli DB, Meckel L, Phillips RE, Radcliffe D, Leggett JE (1983) Moisture stress and nitrogen redistribution in soybean. Agron J75, 1027-1031

Farquhar GD, Sharkey TD (1982) Stomatal conductance and photosynthesis. Annu Rev Plant Physiol 33, 317-345

Fehr WR, Caviness CE (1977) Stages of soybean development. lowa Agric Exp Stn SR-80, 11 pp

Griffin JL, Taylor RW, Habetz RJ, Regan RP (1985) Response of solid-seeded soybeans to flood irrigation: I. Application timing. Agron J 77, 551-554

Hall AE, Foster KW, Waines JG (1979) Agriculture in Semi-Arid Environments (Hall AE, Canell GH, Lawton HW, eds), Springer-Verlag, Berlin, 148-179

Herbest SJ, Litchfield GV (1982) Partitioning soybean yield components. Crop Sci 22, 1074-1079

Hsiao TC (1973) Plant responses to water stress. Annu Rev Plant Physiol 24, 519-570 
Kadhem FA, Specht JE, Williams JH (1985a) Soybean irrigation serially timed during stages $R_{1}$ to $\mathrm{R}_{6}$ : I. Agronomic responses. Agron J 77, 291-298

Kadhem FA, Specht JE, Williams JH (1985b) Soybean irrigation serially timed during stages $R_{1}$ to $\mathrm{R}_{6}$ : II. Yield component responses. Agron $J 77$, 299-304

Korte LL, Williams JH, Specht JE, Sorensen RC (1983a) Irrigation of soybean genotypes during reproductive ontogeny : I. Agronomic responses. Crop Sci 23, 521-527

Korte LL, Specht JE, Williams JH, Sorensen RC (1983b) Irrigation of soybean genotypes during reproductive ontogeny : II. Yield component responses. Crop Sci 23, 528-533

Kramer PJ (1983) Water Relations of Plants. Academic Press Inc, London

Legg BJ, Day W, Lawlor DW, Parkinson KJ (1979) The effects of drought on barley growth: models and measurements showing the relative importance of leaf area and photosynthetic rate. $J$ Agric Sci $92,703-716$

Ludlow MM (1975) Environmental and Biological control of Photosynthesis (Marcelle R, ed) Junk, The Hague, 123-134

Meckel L, Egli DB, Phillips RE, Radcliffe D, Leggett JE (1984) Effect of moisture stress on seed growth in soybeans. Agron J 76, 647-650

Momen NN, Carlson RE, Shaw RH, Arjmand O (1979) Moisture-stress effects on the yield components of two soybean cultivars. Agron J 71, 86-90

Paleg LG, Aspinall D (1981) The Physiology and Biochemistry of Drought Resistance in Plants. Academic Press, NY

Pandey RK, Herrera EAT, Pendleton JW (1984a) Drought response of grain legumes under irrigation gradient: II. Plant water status and canopy temperature. Agron J 76, 553-557
Pandey RK, Herrera WAT, Pendleton JW (1984b) Drought response of grain legumes under irrigation gradient : I. Yield and yield components. Agron $J$ 76, 549-553

Rogers HH, Cure JD, Thomas JF, Smith JM (1984) Influence of elevated $\mathrm{CO}_{2}$ on growth of soybean plants. Crop Sci 24, 361-366

Rosenberg NJ, Blad BL, Verma SB (1983) Microclimate : The Biological Environment. John Wiley and Sons, Inc, NY

Runge EC, Odell RT (1960) The relation between precipitation, temperature, and the yield of soybeans on the agronomy south farm, Urbana, Illinois. Agron $J 52,245-247$

Shibles RM, Weber CR (1966) Interception of solar radiation and dry matter production by various soybean planting patterns. Crop Sci 6, 55-59

Shibles RM, Anderson IC, Gibson AH (1975) Crop Physiology (Evans LT, ed) Cambridge University Press, London, 151-190

Shouse P, Jury WA, Stolzy LH, Dasberg S (1982) Field measurement and modelling of cowpea water use and yield under stressed and well-watered growth conditions. Hilgardia 50, 1-25

Sionit N, Kramer PJ (1977) Effect of water stress during different stages of growth of soybean. Agron $J$ 69, 274-277

Snyder RL, Carlson RE, Shaw RH (1982) Yield of indeterminate soybeans in response to multiple periods of soil-water stress during reproduction. Agron $J 74,855-859$

Thompson LM (1970) Weather and technology in the production of soybeans in the Central United States. Agron J 62, 232-236

Turner NC, Begg JE (1981) Plant-water relations and adaptation to stress. Plant Soil 58, 97-131 